\title{
A Revival of the Romantic Era as seen through a Comparative Study of Auld Lang Syne and Sumer Is Icumen In
}

\author{
Nadia De Souza \\ M.A. English \\ St. Joseph's College \\ Bangalore, India \\ nadiadesouza.eng@gmail.com
}

Abstract

The Romantic Movement of $19^{\text {th }}$ century Britain is often credited to William Wordsworth, while his predecessor, Robert Burns is regarded as the pioneer of the movement with his poetic themes of simplicity, friendship, and reverence for nature and rustic life, to name a few. Yet, on looking back at the medieval ages, one comes across the anonymous poem Sumer Is Icumen In that is centred around similar themes and ideas. This, thus, calls for a more nuanced analysis and understanding of the romantic ideologies that then do not appear to be new to the $19^{\text {th }}$ century, but simply recurrent of what already existed. Therefore, through a comparative study of Robert Burns' Auld Lang Syne and the medieval poem Sumer Is Icumen In, this paper will seek to place Burns either as the pioneer of the romantic movement or as a reviver of a medieval tradition. I will explore the themes, features, and form that persist in these poems.

Keywords: Romantic movement, pantheism, nature, folk tradition, ballad form.

The Romantic era is believed to have begun as a response to the rigidity and the ideology of conduct of the Neo-classical period of the $17^{\text {th }}$ and $18^{\text {th }}$ century. With the Age of 
Enlightenment flourishing around the same time, reason and sophistication were at the centre of focus while imagination was pushed into the background; solitary and rural life were frowned upon and seen as inferior in the face of urban culture. This ideology caused a discomfort among a few in the literary world which ultimately led to a revolution, and the beginning of the Romantic movement. In addition, the agony of the French revolution created a need for nationalism, and shifted the focus from rationality to human nature. While Wordsworth is credited with having been responsible for launching the Romantic movement in the $19^{\text {th }}$ century, initial romantic ideologies are often traced back to Robert Burns at the end of the $18^{\text {th }}$ century. "With the appearance of Burns we can say that the day of Romanticism is come" (Albert 245). His poems reflect images of simple and rustic life, nationality, and sentimentality - themes central to the Romantic ideology.

While Burns is regarded as the "pioneer of the Romantic movement" (Biography.com Editors), one cannot help but notice a similarity in the themes and ideas of Burns' poems and Sumer Is Icumen In of the medieval era, written in middle English. Since the latter was written in the medieval era, there are no records indicating at who the author of the poem might be. However, what can be ascertained is that it is one of the earliest evidences of the folk tradition, and is a possible ancestor of the lyric tradition. Therefore, this paper will seek to discover if Burns was rightly a pioneer of the Romantic movement, or a reviver of the same. The methodology chosen to facilitate this understanding is a comparative study of his poem Auld Lang Syne and the medieval poem, Sumer Is Icumen In. Throughout this paper, we will focus on the themes, features, and form that resonate in both the poems and the Romantic tradition.

To begin with, one must attempt an interpretation of the poems. Auld Lang Syne is a Scottish poem set to the tune of a folk song, and is often translated to "old long since" and "days gone by" (Specktor). "Should auld acquaintance be forgot/ And never brought to 
mind?/ Should old acquaintance be forgot/ And auld lang syne?" (Burns). The lyrics indicate a sense of nostalgia for the past, and a praise for the simple things of life. There is a sense of worth attributed to simple pleasures like a "cup o kindness" (Burns) and human relationships. The idea of friendship is a strong theme in the poem. This was one of the poems that Burns contributed to The Scots Musical Museum, and has since been a very prominent part of the Scottish culture. As mentioned earlier, the French revolution played a significant role in changing the mindset of the people. Therefore, we see human virtues of kindness, trust, and good-will embedded in the poem. The imagery of nature also embellishes the poem in the description of the daisies, the stream, the sea, and the sun. This revert to nature is one of the reasons Burns is seen as an early Romantic.

In Sumer Is Icumen In, we notice a heralding of the new life that summer brings. The cuckoo bird becomes a bridge between the human world and the natural world, and hence, the speaker orders it to sing to announce the arrival of summer. The speaker sees some reassurance in the continuity of life which is represented by the seed. The seed is a symbol of hope to the anxious speaker, and therefore he urges the bird to awaken all of life with its loud song. Even the bullock, the stag, and the cow with their young ones represent this renewal of life. Nature comes to the foreground, and a pantheistic attitude can be noted. In this poem, similar to Auld Lang Syne, and poems of the Romantics, nature is charged with animate life and energy. Nature is seen as a spiritual force that binds all of life together, and therefore must be revered. In addition, while this poem welcomes the presence of summer, it also silently remembers the winter and the inactivity that has passed in the wait for new life. So while there is a celebration of the new, there is also a remembrance of the old. Similarly, Auld Lang Syne is often sung at the stroke of midnight on New Year's Day to reminisce the old while welcoming the new. In certain cultures, it is even sung at funerals, and wedding 
celebrations. Both the poems depict the Romantic practice of a flow and show of emotions expressed through simple language and diction to communicate its message.

During the Romantic era, music was becoming more emotional and subjective than the previous ages run by decorum. "Composers drew inspiration from the folk songs and dances of their country. This nationalist theme can be felt in the music of some Romantic composers whose works were influenced by the history, people, and places of their native country" (Estrella). This idea of folklore and folk song are evident in both the poems being discussed. A salient feature of folklore is its oral tradition. This orality carries in it past cultures, beliefs, rituals and taboos. In literature, oral poetry incudes both, narrative forms like the epic and the ballad, and lyrical forms such as folk songs. Robert Burns is known for his practice of using old Scottish folk songs as tunes for his poems, and even writing and reworking his lyrics in order to fit certain folk songs. "His knowledge of Scottish literature was confined in his childhood to orally transmitted folk songs and folk tales...He regarded his work as service to Scotland and quixotically refused payment” (Robert Burns).

As mentioned earlier, Sumer Is IcumenIn is one of the first evidences of lyric poetry, and belongs to the genre of the folk song. It is also known as the 'Reading Rota' because of its musical ability to be sung in the round (Sumer Is Icumen In). It is not read, rather performed through song and dance. Folk songs contain remnants of older ways of life, and are a way of tying people to nature and their ancestry. However, because it is based in the oral tradition, it is kept alive through memory which if forgotten, can be lost forever. In order to avoid such losses, songs from the folk tradition began to be written down in musical notation so as to be preserved and carried on over time.

Another important feature of the Romantic literary movement was the ballad form. The Encyclopedia Free Dictionary defines a ballad as "a narrative song with a recurrent refrain" or "a narrative poem in short stanzas of popular origin, originally sung to a repeated 
tune" (Ballad). Abrams and Harpham take this a step further by defining a literary ballad as "a narrative poem written in deliberate imitation of the form, language, and spirit of the traditional ballad." (Abrams and Harpham 26). If we examine the poems Auld Lang Syne and Sumer Is Icumen In a little closer, we notice that both the poems appear to be written as a ballad. In the former, there is a clear refrain in the repetition of the lines "For auld lang syne, my dear/ For auld lang syne/ We'll take a cup o' kindness yet/ For auld lang syne” (Burns). The latter does not have as big or as defined of a refrain as Auld Lang Syne, but the words "Sing cuccu nu, sing cuccu" (The Hillard Ensemble) appear often throughout the song, and hence act as the refrain of the song. This musical sensibility and free flow of rhythm seems to have been silenced from the $14^{\text {th }}$ century onwards by a more fixed narrative following the Aristotelian beginning, middle, and end adopted by Chaucer and his successors. The Romantic movement saw a revival of this song tradition, and therefore used the ballad as the primary form for its poetry.

From the evidence provided, it can be seen that Auld Lang Syne and Sumer Is Icumen In are both strongly rooted in the simplicity of life, driven by passion and sentimentality, and governed by imagination. There is reverence for the past as seen in the use of the folk tradition, and a sense of musical flow through the form of the ballad. Thus it is safe to conclude that the Romantic movement of the $19^{\text {th }}$ century was not a new practice, but a revival of an old tradition, and therefore, Robert Burns can be regarded as the pioneer of the revival of the Romantic tradition. 


\section{Works Cited}

Abrams, M. H., and Geoffrey Galt Harpham. A Glossary of Literary Terms. $11^{\text {th }}$ ed., Cengage Learning, 2015.

Albert, Edward. History of English Literature. Edited by J. A. Stone, $5^{\text {th }}$ ed., Oxford University Press, 1979, India.

"Ballad.” Encyclopedia The Free Dictionary, encyclopedia2.thefreedictionary.com/balladic. Accessed 6 July 2019.

Biography.com Editors. "Robert Burns Biography.” www.biography.com/writer/robert-burns. Accessed 2 July 2019.

Burns, Robert. “Auld Lang Syne Lyrics.” Scottish-Folk-Music.com, www.scottish-folkmusic.com/lyrics/auld-lang-syne.htm. Accessed 6 July 2019.

Estrella, Espie. "Music of the Romantic Period.” Liveaboutdotcom, www.liveabout.com/music-forms-and-composers-2456615. Accessed 5 July 2019.

The Hillard Ensemble. "Sumer Is Icumen In.” Lyrics Translate, lyricstranslate.com/en/sumericumen-summer-has-arrived.html. Accessed 6 July 2019.

"Robert Burns.” Encyclopaedia Britannica, www.britannica.com/biography/Robert-Burns. Accessed 2 July 2019.

Specktor, Brandon. “What Does Auld Lang Syne Really Mean?” Reader's Digest, www.rd.com/culture/what-does-auld-lang-syne-mean/. Accessed 6 July 2019.

“Sumer Is Icumen In.” British Library, www.bl.uk/collection-items/sumer-is-icumen-in. Accessed 6 July 2019. 